\title{
Inclusion of psyllium in milk replacer for neonatal calves. 1. Effects on growth, digesta viscosity, rate of passage, nutrient digestibilities, and metabolites in blood ${ }^{1}$
}

\author{
S. J. Cannon, ${ }^{* 2}$ G. C. Fahey Jr., ${ }^{*}$ M. R. Murphy, ${ }^{*}$ C. L. Dikeman, ${ }^{* 3}$ B. L. Miller, $\dagger$ and J. K. Drackley ${ }^{* 4}$ \\ *Department of Animal Sciences, University of Illinois, Urbana 61801 \\ †Land O'Lakes Animal Milk Products, Arden Hills, MN 55126
}

\section{ABSTRACT}

Based on research in other species, inclusion of psyllium in milk replacer might improve nutrient utilization and gastrointestinal function in neonatal calves. Male Holstein calves were fed a milk replacer $(22 \%$ crude protein, $20 \%$ fat) either without or with psyllium (1.1\% of dry matter) from $2 \mathrm{~d}$ through $28 \mathrm{~d}$ of age. Milk replacer was reconstituted to $12.5 \%$ dry matter (DM) and fed at $12 \%$ of calf body weight (BW), adjusted weekly. Water was offered ad libitum but no starter was fed. Three calves per treatment were harvested weekly to sample digesta from the rumen, abomasum, jejunum, proximal colon, and distal colon. Mean daily intakes of water, DM, crude protein, and metabolizable energy did not differ between treatments. Average daily gain of BW did not differ between treatments. Digesta from the abomasum and colon of calves fed psyllium was more viscous than digesta from control calves. Mean retention time of digesta in the total digestive tract tended to be greater for calves supplemented with psyllium (9.7 vs. $8.4 \mathrm{~h}$ ). Feces and digesta from the proximal and distal colon of calves fed psyllium had lower DM content than feces and digesta from control calves. Total-tract apparent digestibility of DM (92.8 vs. $94.1 \%$ ) was lower for psyllium-fed calves, likely as an effect of the addition of the more poorly digestible psyllium; digestibilities of energy and ash also tended to be lower. The prefeeding plasma glucose concentration (10 h after previous feeding) tended to be greater for psyllium-fed calves but concentrations of nonesterified fatty acids, $\beta$-hydroxybutyrate, cholesterol, urea $\mathrm{N}$, and total protein did not differ between treatments. Blood

\footnotetext{
Received September 14, 2009.

Accepted January 4, 2010.

${ }^{1}$ Supported by state and federal funds appropriated to the Illinois Agricultural Experiment Station and by Land O'Lakes Animal Milk Products, Arden Hills, MN.

${ }^{2}$ Present address: Standard Dairy Consultants, 3303 N. Casaloma Dr., Appleton, WI 54913.

${ }^{3}$ Present address: Omaha's Henry Doorly Zoo, 3701 S. 10th St., Omaha, NE 68107-2299.

${ }^{4}$ Corresponding author: drackley@illinois.edu
}

components did not differ between treatments at $2 \mathrm{~h}$ postfeeding. Inclusion of psyllium in the milk replacer of neonatal calves increased digesta viscosity and slowed passage of digesta through the gastrointestinal tract. Key words: psyllium, calf, digesta passage, viscosity

\section{INTRODUCTION}

A major challenge for young calves is gut health. According to the National Animal Health Monitoring System's Dairy 2007 Report (National Animal Health Monitoring System, 2007), 56.5\% of unweaned heifer deaths were attributed to diarrhea or other digestive challenges.

Dietary fibers exert several physiological effects that affect gut function (Mälkki, 2001). Psyllium, a viscous fermentable nonstarch polysaccharide, has been shown to ameliorate diarrhea in other species (Washington et al., 1998; Marlett et al., 2000) and to decrease passage time during cases of constipation (Al-Assaf et al., 2003). Piglets fed milk replacers supplemented with fermentable fiber sources showed enhanced intestinal function and reduced severity of an experimental Salmonella typhimurium infection (Correa-Matos et al., 2003).

Dietary fiber slows the rate of release of nutrients by increasing viscosity of digesta, thereby reducing the rate of nutrient transport to the epithelium (Morris, 2001) and allowing nutrient absorption along a greater length of the small intestine (Blackwood et al., 2000). In dogs, inclusion of psyllium at $3 \%$ of the diet slowed digesta outflow from the stomach (Russell and Bass, 1985). Psyllium inclusion increases the viscosity of intestinal contents (Dikeman et al., 2006), which decreases the rate of absorption of glucose and other nutrients (Blackwood et al., 2000). Psyllium has also been shown to affect glucose metabolism by decreasing the postprandial increase of blood glucose concentration (Weickert and Pfeiffer, 2008).

Fettman (1992) postulated that psyllium would benefit treatment of neonatal calf diarrhea via moderation of gastric emptying, reduction of the rate of glucose absorption, improved carbohydrate tolerance, and VFA 
production in the lower gut. Naylor and Liebel (1995) observed decreased glucose absorption in calves fed a psyllium-supplemented electrolyte solution during diarrhea. Cebra et al. (1998) found that psyllium supplementation of an electrolyte solution caused the calves' feces to become gelatinous and viscous compared with that of control calves; peak glucose and insulin concentrations in blood were lower for calves consuming psyllium. We are unaware of published reports demonstrating effects of long-term dietary supplementation of psyllium to milk replacer in neonatal calves.

Our overall hypothesis was that if the effects observed in other species also occurred in young calves supplemented with psyllium, they might translate to improved health and greater growth efficiency. The objective of this portion of the research was to determine the effect of psyllium inclusion in milk replacer on feed intake, water intake, growth, digesta viscosity, rate of passage, nutrient digestibilities, and blood components in neonatal dairy calves.

\section{MATERIALS AND METHODS}

\section{Animal Care}

All procedures were approved by the University of Illinois Institutional Animal Care and Use Committee (protocol number 04083). The study occurred in 2 periods, the first (May 2004) using 12 calves and the second (June 2004) using 22 calves. Male Holstein calves were purchased from Stone Ridge Dairy (Bellflower, IL) at less than $36 \mathrm{~h}$ of age.

At the beginning of the trial period, daily late-afternoon trips were made to Stone Ridge Dairy to select and purchase calves. All male Holstein calves less than 36 $\mathrm{h}$ of age were evaluated for potential purchase by trial personnel. The evaluation included body temperature, heart and lung auscultation, hydration status, mobility, navel status, and overall thriftiness. The calves must have received at least one feeding of colostrum by Stone Ridge personnel. Calves deemed to be of satisfactory health status according to these criteria were then transported to the University of Illinois Dairy Nutrition Field Laboratory (approximately $42 \mathrm{~km}$ ).

Upon arrival, each calf received a tag in the left ear for identification. Calves were measured for withers height, body length, heart girth circumference, and BW. Mean $\mathrm{BW}( \pm \mathrm{SD})$ was $45.9 \pm 5.2 \mathrm{~kg}$. Ear notches were taken from each calf and placed in formalin for determination of persistently infected bovine viral diarrhea status. Each calf was vaccinated against infectious bovine rhinotracheitis and parainfluenza-3 viruses intranasally (2 mL of TSV-2, Pfizer Animal Health, Exton, PA). In addition, calves received $15 \mathrm{~mL}$ of Quatracon-2X
Antiserum (Boehringer Ingleheim Vetmedica Inc., St. Joseph, MO) subcutaneously in the neck. Each calf also received $2 \mathrm{~mL}$ of Excenel (Pfizer Animal Health) subcutaneously in the neck for the first $3 \mathrm{~d}$ of the study. After entry injections, the calves were moved to southfacing individual calf hutches (Calf-Tel, Hampel Corp., Germantown, WI) on 15 to $20 \mathrm{~cm}$ of crushed limestone located on the south side of the Dairy Nutrition Field Laboratory. No bedding was used, to minimize ingestion of bedding material that might confound treatment inferences.

\section{Assignment to Treatments}

Calves were blocked by pairs based on birth date, BW, and plasma total protein and then randomly assigned within pair to 1 of the 2 dietary treatments. These pairs of calves were then randomly assigned to harvest week. Of the 34 calves assigned to treatments, 1 calf died at $2 \mathrm{~d}$ of age. Necropsy results (University of Illinois College of Veterinary Medicine, Urbana) indicated that the likely cause of mortality was related to birth trauma. All other calves completed the trial in good health.

\section{Feeding}

On the night of arrival, each calf was offered colostrum for ad libitum intake. In the morning following arrival, each calf again was offered colostrum. Treatment feedings were administered at 0600 and $1800 \mathrm{~h}$. Calves were fed milk replacers reconstituted to $12.5 \%$ $\mathrm{DM}$ at a rate of $12 \%$ of BW daily, adjusted weekly as calves grew. Milk replacers (Land O'Lakes Animal Milk Products Co., Arden Hills, MN) without (CON) or with 1.1\% psyllium (PSY) were formulated to contain $22 \% \mathrm{CP}$ and $20 \%$ fat, and contained only milk proteins. Neither milk replacer contained growth-promoting antibiotics. Water was available to calves for ad libitum consumption, with fresh warm water provided twice daily after each milk replacer feeding. No other feeds were offered.

\section{Health Monitoring}

Calves were observed at least twice daily for general health, including appearance (alertness), appetite (ability to consume feed), and fecal scores. Fecal scores were recorded daily using the following guidelines: $1=$ dry, hard; $2=$ soft, formed; $3=$ pudding-like; $4=$ mix of liquids with some solids; and $5=$ liquid. General health concerns were addressed and managed accordingly. If the calf's hydration status was low (skin tenting evident), $500 \mathrm{~mL}$ of lactated Ringer's solution (Ab- 
bott Laboratories, Abbott Park, IL) was administered subcutaneously. If a calf appeared unhealthy, $3 \mathrm{~mL}$ of Excenel (Pfizer Animal Health) was administered subcutaneously for a period of $3 \mathrm{~d}$. If body temperature was over $39^{\circ} \mathrm{C}, 1 \mathrm{~mL}$ of Banamine (Schering-Plough Animal Health, Union, NJ) was administered subcutaneously. Calves received a booster of TSV-2 at 2 wk of age.

\section{Body Growth Measurements}

Calves were weighed weekly before the evening feeding on the same day each week. Growth measurements including withers height, body length, and heart girth were made at the same time.

\section{Blood Sampling}

Blood samples were collected weekly $1 \mathrm{~h}$ before feeding and $3 \mathrm{~h}$ postfeeding on the same day that body measurements were made. Samples were obtained via jugular venipuncture using 20-gauge needles (Becton Dickinson, Franklin Lakes, NJ) into $10-\mathrm{mL}$ vacutainer tubes containing sodium heparin (Becton Dickinson). Tubes were placed on ice and then centrifuged within 2 $\mathrm{h}$ of collection at 1,300 $\times \mathrm{g}$ for $15 \mathrm{~min}$ in an Eppendorf model 5804 centrifuge with swinging buckets (Brinkmann Instruments, Westbury, NY). After centrifugation, the plasma was removed and aliquots placed into 5 -mL Falcon tubes (Becton Dickinson) at $-20^{\circ} \mathrm{C}$ until analysis.

Aliquots of pre- and postprandial plasma were analyzed for concentrations of NEFA (kit number 99075409; Wako Pure Chemical Industries Ltd., Osaka, Japan) with procedural modifications by Johnson and Peters (1993). Concentrations of glucose, total protein, cholesterol, BHBA, and urea $\mathrm{N}$ were determined by enzymatic procedures in an auto-analyzer (University of Illinois Clinical Pathology Laboratory, Urbana).

\section{Calf Harvest Procedure}

Pairs of calves ( 1 from each treatment) were harvested for analysis weekly. For period 1,2 calves were killed after arrival before experimental treatments began (wk 0 ) for baseline measurements. For the remaining weeks, 1 pair of calves was killed weekly, with the exception of wk 4 . In wk 4 of period 1, 2 pairs (4 calves) were killed. For period 2, 4 baseline calves were killed at wk 0 , and 2 pairs were killed during wk 1,2 , and 3 . For wk 4 , only 5 calves were harvested because of the 1 mortality.

Calves were transported to the University of Illinois College of Veterinary Medicine at $0630 \mathrm{~h}$. Calves were not fed their morning milk replacer before euthanasia. The harvest procedure consisted of administration of xylazine $\mathrm{HCl}$ intramuscularly $(50 \mathrm{mg} / \mathrm{mL}$; Fort Dodge Animal Health, Fort Dodge, IA). Once the calf was sedated, it was killed with an intravenous overdose of sodium pentobarbital (Fatal Plus, Veterinary Laboratories Inc., Lenexa, KS) and then exsanguinated. This method was used instead of captive bolt stunning to minimize epithelial sloughing, which could negatively affect measurements of ion transport and histomorphological analyses (Shirazi-Beechey et al., 1989).

When the calf was declared dead, the veterinarian opened the body cavity. The gastrointestinal tract was ligated at the caudal esophagus and rectum and removed as rapidly as possible without damaging the tract. To prevent movement of digesta between compartments, the different segments of the gastrointestinal tract were identified and ligated. The gastrointestinal tract was then divided into 3 portions: the stomach consisting of rumen, reticulum, omasum, and abomasum; the small intestine, consisting of duodenum, jejunum, and ileum; and the colon. Each portion was processed by the respective team of personnel for tissue and digesta collection.

\section{Digesta Collection}

Digesta were removed from the gastrointestinal tract and placed into Whirlpak bags (Nasco, Fort Atkinson, WI). Aliquots were removed at the laboratory for DM determination, and samples for viscosity measurement were stored at $-20^{\circ} \mathrm{C}$ until further analysis. The DM of the digesta was determined by drying an aliquot in an oven at $110^{\circ} \mathrm{C}$ for $24 \mathrm{~h}$.

\section{Total Fecal Collection: Digestibility and Rate of Passage}

To determine rate of passage and digestibility, calves to be harvested at wk 2, 3, and 4 underwent total fecal collections for a period of $5 \mathrm{~d}$. Calves were fitted with canvas sheep fecal bags, modified slightly to account for differences in body structure. These canvas bags were lined with plastic bags to contain the feces excreted by the calf.

To determine the rate of passage, calves were dosed with Co-EDTA. The Co-EDTA was prepared according to the methods of Udén et al. (1980). The solution of Co-EDTA ( $13.8 \%$ cobalt) was made by dissolving the dry material in distilled water at a rate of $17.05 \mathrm{~g} / \mathrm{L}$ of water. This solution was then mixed with the milk replacer fed to the calf at a rate of $10 \mathrm{~mL} / \mathrm{L}$ of milk replacer. Calves consumed this marker for a period of 16 feedings, at which point marker administration ceased and the rate of passage portion of the total collection began. 
The first $48 \mathrm{~h}$ of each total fecal collection period involved fecal collections every $12 \mathrm{~h}$. After the last dose of Co-EDTA was consumed within the milk replacer, collection times shifted to every $6 \mathrm{~h}$ for the remaining $72 \mathrm{~h}$ of collection. When feces were obtained, the plastic bag was placed within a second plastic bag and stored at $-20^{\circ} \mathrm{C}$ until further analysis.

Fecal Dry Weights. Feces were dried individually in a forced-air oven at $60^{\circ} \mathrm{C}$ until constant weights were achieved. Dried feces from the first $48 \mathrm{~h}$ of collection were composited, whereas feces from the rate of passage portion were maintained individually. The dried feces were ground through a 1-mm screen in a Wiley mill (Thomas-Wiley, Swedesboro, NJ).

Sampling and Analysis of Milk Replacers and Feces. Each milk replacer was sampled weekly. Subsamples were combined by treatment and period, and stored at $-20^{\circ} \mathrm{C}$ until analysis could occur concurrently with the fecal analyses to determine apparent digestibility of DM, ash, CP, energy, and long-chain fatty acids. One half of all dried samples of feces (48-h composite and rate of passage samples) were composited to provide samples for analysis of absolute DM, CP, gross energy, long-chain fatty acids, and ash.

Absolute DM was determined in duplicate utilizing the AOAC (1975) method. Ash content was determined by combusting duplicate samples in a muffle furnace for $24 \mathrm{~h}$ at $600^{\circ} \mathrm{C}$. Crude protein was analyzed in duplicate with a Leco Nitrogen/Protein Determinator (model FP-2000, Leco Corporation, St. Joseph, MI) using Official Method 992.15 (AOAC, 2000). Gross energy was determined in duplicate via bomb calorimetry (1261 Isoperibol Calorimeter, Parr Instrument Co., Moline, IL; Parr Instrument Manuals). Long-chain fatty acids were determined by gas chromatography (Shimadzu GC 17-A, Shimadzu Scientific Instruments Inc., Columbia, MD) of methyl esters formed by acid-catalyzed transesterification using the methods of Sukhija and Palmquist (1988), as described by Beaulieu et al. (2002).

Total-tract apparent digestibilities of DM, ash, CP, gross energy, and long-chain fatty acids were calculated as: [(nutrient consumed - nutrient in feces)/nutrient consumed] $\times 100 \%$.

Rate of Passage Analyses. To determine rate of passage, concentrations of cobalt were measured in the feces voided from the calves once Co administration ceased. Cobalt analysis followed the methods of Hart and Polan (1984). Briefly, $20 \mathrm{~mL}$ of $0.05 \mathrm{M}$ EDTA solution was combined with $0.2 \mathrm{~g}$ of dried feces, shaken for $30 \mathrm{~min}$, and filtered through Whatman \#4 filter paper (Whatman International Ltd., Florham Park, NJ). The concentration of $\mathrm{Co}$ in the solutions was then quantified by atomic absorption spectroscopy (air and acetylene flame, Perkin-Elmer, Norwalk, CT). The percentage Co in each sample was calculated as follows:

$$
\text { Co, } \%=\frac{\text { ppm in sample } \times \text { dilution factor }}{\text { sample weight }(\mathrm{g}) \times 10^{6}} \times 100
$$

The model $y(\mathrm{t})=y(0) \cdot \exp (-k t)$ was used to describe the disappearance of Co, where $y$ is the amount of marker present at time $t$ and $k$ is the rate constant. The mean retention time (MRT) then was calculated as the reciprocal of $k$ (Faichney, 1993).

\section{Viscosity}

Viscosity of digesta samples was determined by using methods from Dikeman et al. (2006). Samples were allowed to warm to room temperature $\left(23^{\circ} \mathrm{C}\right)$ and gently mixed with a metal spatula for $30 \mathrm{~s}$ to homogenize the samples. Although significantly lower than physiological temperature, room temperature was used to maintain consistent results with the viscometer configuration used. We assume that viscosity measured at physiological temperature would be lower than the values presented in this study. Aliquots $(2 \mathrm{~mL})$ of rumen, abomasal, and jejunal fluid were removed and used for viscosity measurement. Samples from the rumen, abomasum, and jejunum were analyzed in duplicate using a digital Brookfield viscometer (LV-DV-II+) with a Wells/Brookfield cone and plate extension, either CP40 or CP-41. Colon samples were too viscous to obtain 2-mL aliquots from them. Therefore, a Brookfield LV spindle set (LV-1; LV-2; LV-3) was used with digesta being placed into $100-\mathrm{mL}$ beakers with a diameter of $5 \mathrm{~cm}$. Constants and configurations were programmed into Wingather software (Brookfield Engineering) for viscosity calculations. Viscosity was calculated as a function of rpm over an rpm range of $0.3,0.5,1.0,1.5$, 2.0, and $3.0 \mathrm{rpm}$.

\section{Statistical Analysis}

Statistical analyses were conducted utilizing the Mixed procedure of SAS (version 9.1; SAS Institute Inc., Cary, NC). The data were analyzed as a randomized complete block design, with period as a random effect. Effects of dietary treatment, week, and the interaction of diet and week were included in the model as fixed effects. Baseline calves were not included in the analysis, but means and standard errors are shown for comparison. Significant differences were declared at $P$ $<0.05$, and trends toward significant effects were noted at $P<0.10$. 
Table 1. Composition of milk replacers ${ }^{1}$

\begin{tabular}{lcc}
\hline Nutrient & Control & Psyllium \\
\hline DM, \% & 96.4 & 96.2 \\
CP, \% & 21.8 & 21.6 \\
Lactose, \% & 33.0 & 34.0 \\
Crude fat, \% & 21.00 & 19.95 \\
Ash, ${ }^{2} \%$ & 11.8 & 11.7 \\
Gross energy, ${ }^{3}$ kcal/kg & 4,844 & 4,822 \\
Ca, \% & 0.81 & 0.78 \\
P, \% & 0.74 & 0.72 \\
Mg, \% & 0.13 & 0.13 \\
K, \% & 2.24 & 2.16 \\
Na, \% & 1.24 & 1.20 \\
Fe, mg/kg & 101 & 68 \\
Zn, mg/kg & 24 & 18 \\
Cu, mg/kg & $<1$ & $<1$ \\
Mn, mg/kg & 21 & 22 \\
Mo, mg/kg & 0.50 & 0.45 \\
Psyllium, \% & 0.00 & 1.10 \\
\hline
\end{tabular}

${ }^{1}$ Determined by Dairy One (Ithaca, NY) unless otherwise noted. All values except DM (\% as fed) are expressed on a DM basis.

${ }^{2}$ Determined according to AOAC (1975)

${ }^{3}$ Determined by bomb calorimetry (Parr Instrument Co., Moline, IL).

\section{RESULTS AND DISCUSSION}

Nutrient composition of the diets is shown in Table 1. The PSY milk replacer was produced by addition of $1.1 \%$ psyllium to the CON milk replacer. This inclusion of psyllium resulted in a slight dilution effect, which likely explains why the nutrient values for all ingredients except lactose and manganese were numerically lower in PSY than in CON.

Water intakes did not differ significantly between treatments (Table 2). Intakes of DM, protein, and ME also did not differ between diets (Table 2). Water, DM, protein, and ME intakes increased from wk 1 to 4 ( $P$ $<0.01$ ) as expected (data not shown), but the diet $\times$ week interaction was not significant. Fecal scores and respiratory scores were low and did not differ between treatments (data not shown), nor was there any difference in illness between dietary treatments.
The diet $x$ week interaction was significant for body length (Table 3). Body length tended to increase $(P<$ 0.08 ) from wk 1 to 4 as expected, but increases during wk 1 and 2 were greater for calves fed CON than for those fed PSY. Heart girth increased $(P<0.01)$ from wk 1 to 4 , but effects of diet and the diet $\times$ week interaction were not significant. Withers height was not affected by dietary treatment or age. Body weights increased with age of the calves as expected, but dietary treatments did not affect BW (Table 3). Inclusion of psyllium in the diet, therefore, had a minimal effect on growth measurements in this study. The ADG of BW was lower than that predicted by the NRC (2001) model (Table 3). Possible reasons for this finding include the young age of the calves, the fact that calves had been transported, the effect of experimental procedures performed on the calves, and the degree of heat stress on the calves. Mean daily maximum temperature was $24.4^{\circ} \mathrm{C}$ (range 10.0 to $30.6^{\circ} \mathrm{C}$ ) during period 1 and $26.6^{\circ} \mathrm{C}$ (range 21.1 to $32.8^{\circ} \mathrm{C}$ ) during period 2. These environmental temperatures were consistently greater than the reported upper critical temperature for young calves $\left(15^{\circ} \mathrm{C}\right.$; NRC, 2001$)$.

Inclusion of psyllium in the calf milk replacer increased $(P<0.005)$ viscosities of abomasal and colon digesta (Table 4). Greater viscosity in the abomasum would be expected to slow abomasal emptying, as shown for gastric emptying in dogs (Russell and Bass, 1985). Ruminal and jejunal digesta viscosities did not differ between treatments. Rumen viscosity increased from wk 1 to $4(P<0.08)$, but the diet $\times$ week interaction was not significant. The lack of difference in rumen viscosity is most likely attributable to the fact that the milk replacers mostly bypassed the rumen via the reticular groove in these preruminant calves. Therefore, minimal milk replacer would enter the rumen and contribute to differences in rumen viscosity.

Given the viscous properties of psyllium, it was expected that digesta from the PSY calves would exhibit greater viscosity throughout the gastrointestinal tract,

Table 2. Least squares means and associated standard errors for intakes of water, DM, CP, and ME

\begin{tabular}{|c|c|c|c|c|c|c|}
\hline \multirow[b]{2}{*}{ Intake } & \multicolumn{3}{|c|}{ Overall diet means ${ }^{1}$} & \multicolumn{3}{|c|}{$P$-value ${ }^{2}$} \\
\hline & $\mathrm{CON}$ & PSY & SE & $\mathrm{T}$ & W & $\mathrm{T} \times \mathrm{W}$ \\
\hline \multicolumn{7}{|l|}{ Water, L } \\
\hline Morning & 2.15 & 2.16 & 0.19 & 0.99 & $<0.0001$ & 0.44 \\
\hline Night & 1.21 & 1.58 & 0.21 & 0.12 & 0.01 & 0.30 \\
\hline Total daily & 3.32 & 3.47 & 0.33 & 0.75 & $<0.0001$ & 0.28 \\
\hline DMI, g/d & 712 & 732 & 21.7 & 0.31 & 0.001 & 0.98 \\
\hline Protein, g/d & 155 & 158 & 4.7 & 0.50 & 0.013 & 0.98 \\
\hline $\mathrm{ME}, \mathrm{kcal} / \mathrm{d}$ & 3,175 & 3,105 & 95 & 0.39 & 0.013 & 0.98 \\
\hline
\end{tabular}

${ }^{1} \mathrm{CON}=$ control diet; PSY $=$ psyllium-supplemented diet.

${ }^{2} \mathrm{~T}=$ effect of treatment, $\mathrm{W}=$ effect of week, $\mathrm{T} \times \mathrm{W}=$ treatment $\times$ week interaction. 
Table 3. Least squares means and associated standard errors for BW and average daily growth

\begin{tabular}{lccccccc}
\hline & \multicolumn{3}{c}{ Overall diet means $^{1}$} & & \multicolumn{3}{c}{$P$-value } \\
\cline { 2 - 4 } \cline { 6 - 8 } Variable & CON & PSY & SE & & T & W & $\mathrm{T} \times \mathrm{W}$ \\
\hline Beginning BW, kg & 45.9 & 44.4 & 1.3 & & 0.42 & - & - \\
BW, kg/d & 0.29 & 0.27 & 0.04 & & 0.66 & $<0.001$ & 0.82 \\
Body length, cm/d & 0.20 & 0.12 & 0.05 & & 0.17 & 0.08 & 0.04 \\
Heart girth, cm/d & 0.19 & 0.17 & 0.04 & & 0.76 & 0.01 & 0.94 \\
Withers height, cm/d & 0.22 & 0.19 & 0.05 & & 0.71 & 0.85 & 0.69 \\
Predicted BW gain, ${ }^{3} \mathrm{~kg} / \mathrm{d}$ & 0.49 & 0.51 & - & & - & - & - \\
\hline
\end{tabular}

${ }^{1} \mathrm{CON}=$ control diet; PSY $=$ psyllium-supplemented diet.

${ }^{2} \mathrm{~T}=$ effect of treatment, $\mathrm{W}=$ effect of week, $\mathrm{T} \times \mathrm{W}=$ treatment $\times$ week interaction

${ }^{3}$ Predicted ADG (apparent digestible protein -allowable) according to the NRC (2001) model, assuming average BW of $50 \mathrm{~kg}$ and $48 \mathrm{~kg}$ for CON and PSY calves, and DMI as shown in Table 2.

as seen in abomasal and colonic digesta. The lack of difference in jejunal viscosity (Table 4) was surprising, but at least 2 explanations may be proposed. First, digesta were sampled $>12 \mathrm{~h}$ after the last feeding, when most of the milk replacer would have been digested or passed further down the tract. During simulated small intestinal digestion of fiber sources including psyllium, viscosity increased and peaked between 3 and $12 \mathrm{~h}$, and then dropped by $18 \mathrm{~h}$ (Dikeman et al., 2006). Second, the inclusion rate of psyllium may have been too low to significantly affect viscosity in the jejunum.

A trend $(P=0.10)$ was observed for increased MRT for calves fed the PSY milk replacer (Table 4). This increase in MRT for the PSY calves could be attributed to the increased viscosity of the digesta delaying gastric emptying, as observed in studies with other species (Russell and Bass, 1985; Washington et al., 1998). Passage rate was decreased in pigs supplemented with guar gum (Owusu-Asiedu et al., 2006).
No significant differences were observed between treatments in DM content of rumen digesta (Table 4), probably because little milk replacer entered the rumen. Differences between diets also were not significant for digesta DM content of the abomasum and jejunum, although means were numerically lower for calves fed PSY. The digesta in the proximal colon $(P<0.02)$ and distal colon $(P<0.02)$ of calves fed PSY exhibited a lower DM content compared with CON calves, most likely because of the water-holding capacity of psyllium. These data are similar to those of McRorie et al. (1998), who found that the water content of the colonic digesta in pigs supplemented with psyllium was significantly increased in the 9 most distal bowel segments of the 13 segments evaluated. They concluded that psyllium was able to resist the dehydrational effects of the distal colon, resulting in softer digesta and feces.

The PSY calves produced more fecal DM output than CON calves $(P<0.03$; Table 5$)$. Increased fecal output

Table 4. Least squares means and associated standard errors for viscosity of digesta, mean retention time (MRT) of digesta in the total tract, and DM content of digesta

\begin{tabular}{|c|c|c|c|c|c|c|}
\hline \multirow[b]{2}{*}{ Variable } & \multicolumn{3}{|c|}{ Overall diet means ${ }^{1}$} & \multicolumn{3}{|c|}{$P$-value ${ }^{2}$} \\
\hline & $\mathrm{CON}$ & PSY & $\mathrm{SE}$ & $\mathrm{T}$ & W & $\mathrm{T} \times \mathrm{W}$ \\
\hline \multicolumn{7}{|c|}{ Digesta viscosity, cP } \\
\hline Rumen & 10.2 & 8.8 & 0.98 & 0.33 & 0.08 & 0.25 \\
\hline Abomasum & 18.1 & 34.1 & 6.9 & 0.004 & 0.28 & 0.77 \\
\hline Jejunum $^{3}$ & 21.4 & 19.9 & 4.8 & 0.69 & 0.36 & 0.54 \\
\hline Colon $^{3}$ & 3.67 & 4.74 & 0.14 & $<0.001$ & 0.16 & 0.24 \\
\hline MRT, h & 8.45 & 9.71 & 0.59 & 0.10 & 0.93 & 0.76 \\
\hline \multicolumn{7}{|l|}{ Digesta DM, \% } \\
\hline Rumen & 1.5 & 1.7 & 0.00 & 0.52 & 0.18 & 0.32 \\
\hline Abomasum & 3.8 & 2.7 & 0.01 & 0.28 & 0.30 & 0.52 \\
\hline Jejunum & 8.2 & 7.6 & 0.01 & 0.55 & 0.38 & 0.62 \\
\hline Proximal colon & 17.3 & 13.8 & 0.01 & 0.02 & 0.74 & 0.84 \\
\hline Distal colon & 20.9 & 17.8 & 0.01 & 0.05 & 0.10 & 0.65 \\
\hline
\end{tabular}

${ }^{1} \mathrm{CON}=$ control diet; PSY $=$ psyllium-supplemented diet.

${ }^{2} \mathrm{~T}=$ effect of treatment, $\mathrm{W}=$ effect of week, $\mathrm{T} \times \mathrm{W}=$ treatment $\times$ week interaction.

${ }^{3}$ Data were $\log _{10}$ transformed for statistical analysis, but back-transformed means are shown for ease of interpretation. 
Table 5. Least squares means and associated standard errors for fecal output, fecal DM, and total-tract apparent digestibilities ${ }^{1}$

\begin{tabular}{|c|c|c|c|c|c|c|c|c|c|c|c|c|c|c|c|}
\hline Item & \multicolumn{3}{|c|}{ Week 2} & \multicolumn{3}{|c|}{ Week 3} & \multicolumn{3}{|c|}{ Week 4} & \multicolumn{3}{|c|}{ Overall diet means } & \multicolumn{3}{|c|}{$P$-value ${ }^{2}$} \\
\hline \multicolumn{16}{|l|}{ 5-d Total fecal output, } \\
\hline Fecal DM, \% & 21.8 & 16.6 & 1.7 & 18.7 & 16.2 & 1.7 & 21.2 & 16.9 & 1.5 & 20.6 & 16.5 & 0.01 & 0.007 & 0.48 & 0.71 \\
\hline \multicolumn{16}{|l|}{ Digestibilities, \% } \\
\hline DM & $94.1^{\mathrm{a}}$ & $91.2^{\mathrm{b}}$ & 0.7 & 93.5 & 94.3 & 0.7 & $94.6^{\mathrm{c}}$ & $93.0^{\mathrm{d}}$ & 0.6 & 94.1 & 92.8 & 0.4 & 0.027 & 0.132 & 0.035 \\
\hline C16:0 & 99.0 & 98.6 & 0.22 & 99.2 & 99.6 & 0.22 & 99.5 & 99.2 & 0.19 & 99.2 & 99.1 & 0.12 & 0.63 & 0.029 & 0.21 \\
\hline C18:0 & 96.4 & 95.8 & 0.79 & 98.9 & 97.5 & 0.79 & 98.5 & 97.8 & 0.69 & 97.5 & 97.5 & 0.44 & 0.95 & 0.028 & 0.31 \\
\hline C18:1cis & 99.8 & 99.8 & 0.48 & 99.8 & 99.9 & 0.48 & 99.9 & 99.8 & 0.48 & 99.8 & 99.8 & 0.03 & 0.92 & 0.21 & 0.17 \\
\hline Total fatty acids & 99.1 & 99.9 & 0.19 & 99.3 & 99.7 & 0.19 & 99.5 & 99.4 & 0.16 & 99.3 & 99.3 & 0.1 & 0.93 & 0.027 & 0.23 \\
\hline
\end{tabular}

${ }^{\mathrm{a}, \mathrm{b}}$ Subcolumn means within row and week category with different superscripts differ $(P<0.01)$.

${ }^{\mathrm{c}, \mathrm{d}, \mathrm{g}, \mathrm{h}}$ Subcolumn means within row and week category with different superscripts differ $(P<0.10)$.

${ }_{\mathrm{e}, \mathrm{f}, \mathrm{o}, \mathrm{p}}$ Subcolumn means within row and week category with different superscripts differ $(P<0.05)$.

${ }^{\mathrm{i}, \mathrm{j}}$ Subcolumn means within row and week category with different superscripts differ $(P<0.02)$.

${ }^{\mathrm{k}, \mathrm{l}}$ Subcolumn means within row and week category with different superscripts differ $(P<0.20)$.

${ }^{\mathrm{m}, \mathrm{n}}$ Subcolumn means within row and week category with different superscripts differ $(P<0.15)$.

${ }^{1} \mathrm{CON}=$ control diet; PSY $=$ psyllium-supplemented diet

${ }^{2} \mathrm{~T}=$ effect of treatment, $\mathrm{W}=$ effect of week, $\mathrm{T} \times \mathrm{W}=$ treatment $\times$ week interaction.

with dietary psyllium also has been observed in rats (Leng-Peschlow, 1991; Edwards et al., 1992; Asvarujanon et al., 2004). Fecal DM content was lower for the PSY calves $(P<0.01)$. Similar to the colonic digesta, lower fecal DM likely reflects the greater water-holding capacity of psyllium, increasing the fecal water content as observed in monkeys fed psyllium (Costa et al., 1989). Furthermore, a gel-like quality was observed in the feces of PSY calves, supporting similar observations in monkeys (McCall et al., 1992), humans (Marlett et al., 2000), and calves (Cebra et al., 1998).

The apparent digestibility of DM was greater $(P<$ $0.03)$ for the CON calves (Table 5 ), and digestibility of energy tended $(P<0.10)$ to be greater. Lower apparent digestibility of DM and energy for calves fed PSY could be a result of the dilution effect of psyllium inclusion, which as a fermentable dietary fiber source is still less digestible than the other ingredients in milk replacer. In addition, a significant treatment $\times$ week interaction $(P<0.035)$ was observed. Differences between treatments were greatest during wk 2 and least during wk 3. Similar dietary effects and interactions between dietary treatment and week were also noted for digestibilities of energy, ash, and CP (Table 5). In a similar manner, addition of guar gum, another source of fermentable fiber, decreased total-tract digestibility of energy in pigs (Owusu-Asiedu et al., 2006).

The CON calves tended to have increased ash digestibility compared with the PSY calves, particularly during wk 2 and 4 (treatment $\times$ week interaction, $P$ $<0.06)$. In rats, it has been shown that increased vis- cosity can decrease mineral absorption (Asvarujanon et al., 2004). The viscous nature of psyllium allows for entrapment of minerals within its matrix, thereby potentially decreasing absorption; however, this aspect has not been extensively researched. Although psyllium has been shown to decrease the rate of nutrient absorption (Blackwood et al., 2000), effects on the extent of absorption are not fully understood.

No significant effects of treatment $(P \geq 0.63)$ were observed for digestibilities of the long-chain fatty acids C16:0, C18:0, C18:1cis, or total fatty acids (Table 5). However, an effect of week was noted for C16:0 $(P<$ $0.03)$ and $\mathrm{C} 18: 0(P<0.03)$ : digestibilities increased with age. No diet $x$ week interactions were noted for fatty acid digestibilities. The increased digestibility of the saturated fatty acids C16:0 and C18:0 with advancing age of the calves is of interest because these fatty acids are predominant in small intestinal digesta of functioning ruminants; absorption of these saturated free fatty acids requires the lysolecithin system (Spanski et al., 1997). To our knowledge, age-dependent increases in digestibilities of C16:0 and C18:0 in calves of this age and fed milk replacer only have not been reported previously.

Psyllium has been used in humans to slow the rate of glucose absorption and to blunt the postprandial increase in blood glucose (Sierra et al., 2002; Weickert and Pfeiffer, 2008). In our study, there was no difference in postprandial glucose concentrations between the PSY and CON treatments (Table 6). However, the PSY calves tended $(P<0.064)$ to have a higher blood 
Table 6. Least squares means and associated standard errors for blood constituents

\begin{tabular}{|c|c|c|c|c|c|c|c|c|}
\hline Variable & \multicolumn{2}{|c|}{ Week 0} & \multicolumn{3}{|c|}{ Overall diet means $^{1}$} & \multicolumn{3}{|c|}{$P$-value ${ }^{2}$} \\
\hline \multicolumn{9}{|l|}{ Preprandial values } \\
\hline Glucose, mg/dL & 102.6 & 3.2 & 94.6 & 99.2 & 4.2 & 0.06 & 1.00 & 0.67 \\
\hline NEFA, $\mu \mathrm{Eq} / \mathrm{L}$ & 395 & 29.5 & 244 & 231 & 22 & 0.52 & 0.01 & 0.66 \\
\hline BHBA, mmol/L & 0.06 & 0.01 & 0.06 & 0.06 & 0.01 & 0.80 & 0.08 & 0.96 \\
\hline Cholesterol, mg/dL & 27.9 & 1.6 & 75.1 & 71.6 & 2.5 & 0.28 & $<0.001$ & 0.12 \\
\hline \multicolumn{9}{|l|}{ Postprandial values } \\
\hline Glucose, mg/dL & 103.6 & 4.23 & 102.5 & 105.7 & 2.8 & 0.42 & 0.073 & 0.87 \\
\hline $\mathrm{NEFA}, \mu \mathrm{Eq} / \mathrm{L}$ & 261 & 22.4 & 191 & 185 & 12.6 & 0.73 & 0.013 & 0.52 \\
\hline BHBA, mmol/L & 0.05 & 0.01 & 0.02 & 0.02 & 0.01 & 0.45 & $<0.001$ & 0.74 \\
\hline Cholesterol, mg/dL & 26.4 & 1.3 & 67.9 & 68.1 & 3.0 & 0.96 & $<0.001$ & 0.18 \\
\hline Urea N, mg/dL & 12.0 & 0.98 & 6.2 & 5.8 & 0.73 & 0.44 & 0.89 & 0.64 \\
\hline Total protein, mg/dL & 5.10 & 0.43 & 5.13 & 5.10 & 0.61 & 0.99 & 0.018 & 0.76 \\
\hline
\end{tabular}

${ }^{1} \mathrm{CON}=$ control diet; PSY $=$ psyllium-supplemented diet.

${ }^{2} \mathrm{~T}=$ effect of treatment, $\mathrm{W}=$ effect of week, $\mathrm{T} \times \mathrm{W}=$ treatment $\times$ week interaction.

${ }^{3}$ Baseline values are shown for informational purposes and are not included in the statistical analyses.

glucose concentration preprandially (i.e., $10 \mathrm{~h}$ postprandial, Table 6). This finding could be the result of the viscous nature of psyllium slowing the rate of glucose absorption over a longer period. It is also possible that the CON calves had a higher insulin response to dispose of elevated glucose concentrations postprandially, but blood insulin concentrations were not measured in this study. A diet high in soluble fiber decreased diurnal variation in concentrations of glucose and insulin in sows (Serena et al., 2009).

Concentrations of NEFA, BHBA, cholesterol, urea $\mathrm{N}$, and total protein were not different between treatments (Table 6$)$ either preprandially $(P \geq 0.28)$ or postprandially $(P \geq 0.44)$. However, an effect of week (i.e., age of calves) was observed for preprandial values of NEFA (decrease, $P<0.01$ ), BHBA (increase, $P<$ 0.08 ), and cholesterol (increase, $P<0.001$ ). Furthermore, an effect of week was observed for postprandial values of NEFA (decrease, $P<0.01$ ), BHBA (increase, $P<0.001$ ), cholesterol (increase, $P<0.001$ ), and total protein (decrease, $P<0.02$ ). No significant treatment $\times$ week interactions were observed.

\section{CONCLUSIONS}

Addition of psyllium to milk replacer increased viscosity of digesta, increased digesta MRT, and decreased DM content of colonic digesta and feces in neonatal dairy calves. These effects could be of benefit to nutrient utilization and gut health in neonatal dairy calves. Total-tract apparent digestibilities were decreased slightly by inclusion of psyllium, likely because of inclusion of the lower digestibility psyllium into the milk replacer. Although psyllium did not affect growth of calves in this study, the physiological changes observed suggest that effects of psyllium supplementation should be tested in large numbers of calves under more typical field conditions. It would also be of interest to evaluate digestibilities and growth of dairy calves fed larger amounts of milk replacer with calf starter, compared with this trial in which only limited amounts of milk replacer were fed. The moderation of blood glucose concentrations with psyllium in the diet is an interesting finding, particularly as it pertains to efficiency of growth of neonatal dairy calves. Whether this effect is repeatable and would be observed in calves also fed starters is an area for future research, as is the possible mechanism for the effect.

\section{ACKNOWLEDGMENTS}

The authors acknowledge the assistance of the graduate and undergraduate students in the Drackley laboratory (University of Illinois, Urbana), R. L. Wallace (University of Illinois, Urbana) for assistance with euthanasia and dissection, and A. Norman Schmillen (University of Illinois, Urbana) for technical support. The authors also appreciate the statistical expertise of G. A. Bollero (University of Illinois, Urbana).

\section{REFERENCES}

Al-Assaf, S., G. O. Phillips, P. A. Williams, S. Takigami, P. Dettmar, and M. Havler. 2003. Molecular weight, tertiary structure, water binding and colon behaviour of ispaghula husk fibre. Proc. Nutr. Soc. 62:211-216.

AOAC. 1975. Official Methods of Analysis. 12th ed. Association of Official Analytical Chemists, Washington, DC.

AOAC. 2000. Official Methods of Analysis. 17th ed. Association of Official Analytical Chemists, Washington, DC. 
Asvarujanon, P., S. Ishizuka, and H. Hara. 2004. Inhibitory effects of psyllium on rat mineral absorption were abolished by reduction of viscosity with partial hydrolysis. Biosci. Biotechnol. Biochem. 68:1737-1742.

Beaulieu, A. D., J. K. Drackley, and N. R. Merchen. 2002. Concentrations of conjugated linoleic acid (cis-9, trans-11-octadecadienoic acid) are not increased in tissue lipids of cattle fed a high-concentrate diet supplemented with soybean oil. J. Anim. Sci. 80:847-861.

Blackwood, A. D., J. Salter, P. W. Dettmar, and M. F. Chaplin. 2000. Dietary fibre, physicochemical properties and their relationship to health. J. R. Soc. Health 120:242-247.

Cebra, M. L., F. B. Garry, C. K. Cebra, R. Adams, J. P. McCann, and M. Fettman. 1998. Treatment of neonatal calf diarrhea with an oral electrolyte solution supplemented with psyllium mucilloid. J. Vet. Intern. Med. 12:449-455.

Correa-Matos, N. J., S. M. Donovan, R. E. Isaacson, H. R. Gaskins, B. A. White, and K. A. Tappenden. 2003. Fermentable fiber reduces recovery time and improves intestinal function in piglets following Salmonella typhimurium infection. J. Nutr. 133:1845-1852.

Costa, M. A., T. Mehta, and J. R. Males. 1989. Effects of dietary cellulose, psyllium husk, and cholesterol level on fecal and colonic microbial metabolism in monkeys. J. Nutr. 119:986-992.

Dikeman, C. L., M. R. Murphy, and G. C. Fahey Jr.. 2006. Dietary fibers affect viscosity of solutions and simulated human gastric and small intestinal digesta. J. Nutr. 136:913-919.

Edwards, C. A., J. Bowen, W. G. Brydon, and M. A. Eastwood. 1992. The effects of ispaghula on rat caecal fermentation and stool output. Br. J. Nutr. 68:473-482.

Faichney, G. J. 1993. Digesta Flow. Page 70 in Quantitative Aspects of Ruminant Digestion and Metabolism. J. M. Forbes and J. France, ed. University Press, London, UK.

Fettman, M. 1992. Potential benefits of psyllium mucilloid supplementation of oral replacement formulas for neonatal calf scours. Food Anim. Compend. 14:247-255.

Hart, S. P., and C. E. Polan. 1984. Simultaneous extraction and determination of ytterbium and cobalt ethylenediaminetetraacetate complex in feces. J. Dairy Sci. 677:888-892.

Johnson, M. M., and J. P. Peters. 1993. Technical note: An improved method to quantify nonesterified fatty acids in bovine plasma. J. Anim. Sci. 71:753-756.

Leng-Peschlow, E. 1991. Plantago ovata seeds as dietary fibre supplement: Physiological and metabolic effects in rats. Br. J. Nutr. 66:331-349.

Mälkki, A. 2001. Physical properties of dietary fiber as keys to physiological functions. Cereal Foods World 46:196-199.

Marlett, J. A., T. M. Kajs, and M. H. Fischer. 2000. An unfermented gel component of psyllium seed husk promotes laxation as a lubricant in humans. Am. J. Clin. Nutr. 72:784-789.

McCall, M. R., T. Mehta, C. W. Leathers, and D. M. Foster. 1992. Psyllium husk. I: Effect on plasma lipoproteins, cholesterol metabolism, and atherosclerosis in African green monkeys. Am. J. Clin. Nutr. 56:376-384.
McRorie, J., S. Pepple, and C. Rudolph. 1998. Effects of fiber laxatives and calcium docusate on regional water content and viscosity of digesta in the large intestine of the pig. Dig. Dis. Sci. 43:738 745 .

Morris, E. R. 2001. Assembly and Rheology of Non-Starch PolysaccharidesPages 30-41 in Advanced Dietary Fibre Technology. B. V. McCleary and L. Prosky, ed. Blackwell Science Ltd., Oxford, UK.

National Animal Health Monitoring System. 2007. Part 1: Reference of Dairy Cattle Health and Management Practices in the United States, 2007. USDA:APHIS:VS:CEAH, Ft. Collins, CO.

Naylor, J. M., and T. Liebel. 1995. Effect of psyllium on plasma concentration of glucose, breath hydrogen concentration, and fecal composition in calves with diarrhea treated orally with electrolyte solutions. Am. J. Vet. Res. 56:56-59.

NRC. 2001. Nutrient Requirements of Dairy Cattle. 7th rev. ed. Natl. Acad. Sci., Washington, DC.

Owusu-Asiedu, A., J. F. Patience, B. Laarveld, A. G. Van Kessel, P. H. Simmins, and R. T. Zijlstra. 2006. Effects of guar gum and cellulose on digesta passage rate, ileal microbial populations, energy and protein digestibility, and performance of grower pigs. J. Anim. Sci. 84:843-852.

Russell, J., and P. Bass. 1985. Canine gastric emptying of fiber meals: Influence of meal viscosity and antroduodenal motility. Am. J. Physiol. 249:G662-G667.

Serena, A., H. Jørgensen, and K. E. Bach Knudsen. 2009. Absorption of carbohydrate-derived nutrients in sows as influenced by types and contents of dietary fiber. J. Anim. Sci. 87:136-147.

Shirazi-Beechey, S. P., R. B. Kemp, J. Dyer, and R. B. Beechey. 1989 Changes in the functions of the intestinal brush border membrane during the development of the ruminant habit in lambs. Comp. Biochem. Physiol. 94B:801-806.

Sierra, M., J. J. Garcia, N. Fernández, M. J. Diez, and A. P. Calle., and Farmafibra Group. 2002. Therapeutic effects of psyllium in type 2 diabetic patients. Eur. J. Clin. Nutr. 56:830-842.

Spanski, N. A., J. K. Drackley, C. L. Davis, and E. H. Jaster. 1997. Utilization of supplemental triglycerides or free fatty acids by calves from 4 to 10 weeks of age. J. Dairy Sci. 80:573-585.

Sukhija, P. S., and D. L. Palmquist. 1988. Rapid method for determination of total fatty acid contend and composition of feed stuffs and feces. J. Agric. Food Chem. 36:1202-1206.

Udén, P., P. E. Colucci, and P. J. Van Soest. 1980. Investigation of chromium, cerium, and cobalt as markers in digesta. Rate of passage studies. J. Sci. Food Agric. 31:625-632.

Washington, N., M. Harris, A. Musselwhite, and R. C. Spiller. 1998. Moderation of lactulose-induced diarrhea by psyllium: Effects on motility and fermentation. Am. J. Clin. Nutr. 67:317-321.

Weickert, M. O., and A. F. H. Pfeiffer. 2008. Metabolic effects of dietary fiber consumption and prevention of diabetes. J. Nutr. 138:439-442. 